\title{
The Potential Effect of Aqueous Extract of Detarium microcarpum Bark on Certain Metabolic Disorders Associated with an Atherogenic Diet in Rats
}

\author{
Youovop Fotso Janvier ${ }^{1}$, Mbaississem Walendom Dieudonné ${ }^{1}$, Ngondi Judith Laure ${ }^{1} \&$ Julius Enyong Oben $^{1}$ \\ ${ }^{1}$ Department of Biochemistry, Faculty of Science, University of Yaounde 1, Yaounde, Cameroon \\ Correspondence: Ngondi Judith Laure, Department of Biochemistry, Faculty of Science, University of Yaounde \\ 1, Yaounde, Cameroon. E-mail: ngondijudithl@hotmail.com
}

Received: July 2, $2020 \quad$ Accepted: July 27, $2020 \quad$ Online Published: September 15, 2020

doi:10.5539/jfr.v9n5p102 URL: https://doi.org/10.5539/jfr.v9n5p102

\begin{abstract}
Atherosclerosis is the leading cause of the cardiovascular disease (CVD). This study aimed to evaluate the effect of the aqueous extract of Detarium microcarpum on metabolic disorders in rats fed with an atherogenic diet. The extract at two doses $(200 \mathrm{mg} / \mathrm{kg}$ and $400 \mathrm{mg} / \mathrm{kg})$ was co-administered in rats with an atherogenic diet. After 28 days, rats were sacrificed, blood collected in ethylene diamine tetraacetic acid (EDTA) tubes for plasma preparation, and the heart used for homogenate preparation. These plasma and heart homogenates were used to assess lipid profile, cardiac function (NO, ASAT), and hepatic function (ALAT, ASAT, and totals proteins). The results obtained showed that treatment $(200 \mathrm{mg} / \mathrm{kg}$ and $400 \mathrm{mg} / \mathrm{kg}$ extract) led to a significant decrease in TG, VLDL-c, LDL-c, HDL-c, and non-HDL-c compared to untreated rats (positive control) ( $\mathrm{p}<0.001$ ). Similarly, the cardiovascular risk index (IR, CRR, AC and AIP), were significantly low in the treated groups compared to untreated groups $(\mathrm{p}<0.001)$. Meanwhile, the CPI was higher in threated groups $(\mathrm{p}<0.001)$. The percentage of vascular protection in rats receiving the extract was higher compared to rats treated with atorvastatin. The evaluation of cardiac function showed high levels of NO and ASAT in the heart of rats treated with the extract (p $<0.05)$. The plasma activity of ASAT and ALAT was low in the groups treated with the extract $(\mathrm{p}<0.05)$. A low plasma level of total protein was also observed in the same groups $(\mathrm{p}<0.001)$. Therefore, the aqueous bark extract of D. microcarpum administered orally showed anti-atherogenic, cardioprotective, and hepatoprotective potential.
\end{abstract}

Keywords: Anti atherogenic, atherogenic diet, cardioprotective, cardiovascular risk, Detarium microcarpum, and hepatoprotective

\section{Introduction}

Cardiovascular disease (CVD) is a category of diseases that involves the heart or blood vessels such as coronary heart disease, myocardial infarction, and angina pectoris, causing deaths in both developed and developing countries (Shafiee-Nick et al., 2017; WHO, 2018). The development and progression of CVD are associated with several risk factors such as dyslipidemia or dyslipoproteinemia, hypertension, hyperglycemia, insulin resistance, obesity, and atherosclerosis (Brunzell et al., 2008). Most cases of CVD complications result from atherosclerosis (Habauzit \& Morand, 2012).

Atherosclerosis, which develops mainly in the arteries, is strongly associated with dyslipidemia characterized by high plasma levels of VLDL-c, LDL-c, total cholesterol (TC), non-HDL-c, triglycerides (TG), and low levels of HDL-c. Non-HDL-c represents the major lipoprotein group linked with a higher risk of cardiovascular diseases. Indeed, the increase in plasma cholesterol levels leads to a change in the impermeability of arterial endothelial cells, thus allowing lipids, particularly LDL-c particles, to migrate into the arterial wall (Al-Qahtany et al., 2018). Once in the subendothelial space, these small LDL-c particles will be oxidized causing the endothelial cells to express the adhesion molecules ICAM-1, VCAM-1, E, and P-selectin (Prasad et al., 2014). These adhesion molecules expressed on the endothelial surface will recruit circulating monocytes that will differentiate into macrophages. These macrophages, by expression of the receptors A, B1, CD36, CD68 will massively accumulate cholesterol (Bergheanu, Bodde \& Jukema, 2017) and transform into foamy cells. The atherogenic process will continue with a set of vascular modifications. These changes include fat streaks, chronic 
inflammation, pathological thickening of the intima, the appearance of fibrous plaques vulnerable to rupture, thrombosis, or stenosis (Aziz \& Yadav, 2016). The initiation and evolution of the atherosclerotic process are strongly associated with oxidative stress which is characterized by an increase in the production of reactive oxygen species (ROS). These ROS cause a narrowing of the arterial wall (vasoconstriction) at the vascular level by decreasing the bioavailability of nitric oxide (NO) and the loss of intracellular tissue components (liver, hearts, kidneys, brain) as well as their function by altering their membrane architecture (lipoperoxidation). This damage caused by ROS is due to their toxicity on lipids, proteins, and nucleic acids which are major components of cells (Valko, Rhodes, Moncol, Izakovic \& Mazur, 2006). Given the complexity of the mechanisms involved in atherogenesis and the associated complications, the search for new compounds with multiple pathways of action is becoming a necessity.

Polyphenols, especially flavonoids, are compounds derived from plants with variable biological properties. They have beneficial effects on vascular health (inhibition of LDL-c oxidation), dyslipidemia (decrease in LDL-c, TC, TG and increase in HDL-c), inflammation (decrease in pro-inflammatory cytokine production), diabetes (hypoglycemic and insulin sensitizer effect), antioxidant, endothelial dysfunction (inhibits the expression of adhesion molecules, promotes vasodilatation) (Morand \& Milenkovic, 2014; Amiot, Riva \& Vinet, 2016). For several decades, low-income populations have been using medicinal plants for the management of several pathologies. Detarium microcarpum or small sweet detar, a woody plant of the Fabaceae family (Sani, Agunu, Danmalam \& Ibrahim, 2014), is one of these plants. In traditional medicine, the decoction or maceration of the leaves, roots, fruits, and bark of this plant is used to treat constipation, meningitis, arthritis, tuberculosis, hypertension, and rheumatism (Sani, Agunu, Danmalam \& Ibrahim, 2014; Oibiokpa, Godwin, Abubakar \& Kudirat, 2014). The decoction of the stem bark is traditionally used in the treatment of hemorrhoids, blennorrhoea, simple and sanguinolent diarrhea (Adama, 1997). The studies carried out by Hama, Ouedraogo \& Adama in 2019, on the methanolic extract of various organs of this plant revealed that the stem bark contained more polyphenols and had a better antioxidant activity in vitro. View its antioxidant activity correlated with the polyphenols they contain; this study was carried out to evaluate some biological activities of Detarium microcarpum stem bark extract in rats fed with an atherogenic a diet. The effect on lipid profile, atherogenic index, markers of cardiac and hepatic function was evaluated.

\section{Methodology}

\subsection{Reagents}

Analytical grade reagents used were purchased from Sigma Aldrich (USA). They were: Folin-ciocalteu reagent, catechin, ethanol, aluminum chloride, potassium acetate, quercetin, sodium chloride, sulfanilamide, naphthyl ethylene diamine dichloride, bovine serum albumin, orthophosphoric acid, L-alanine, L-aspartate, alpha-ketoglutarate, mono, and disodium phosphate.

\subsection{Plant Material}

The stem bark of D. microcarpum was collected in Kousseri (Far North region of Cameroon) and identified at Cameroon national herbarium as No. 49834. These barks were then dried at ambient temperature in a dark room, ground to a powder, and used to prepare the aqueous extract.

\subsection{Extraction}

The aqueous extract was prepared by decoction. Briefly, $500 \mathrm{~g}$ of powder was dissolved in $4 \mathrm{~L}$ of distilled water. The extraction ratio was $1 / 8(\mathrm{w} / \mathrm{v})$. The mixture was homogenized and then brought to a boil for 45 minutes. The decoction from this boiling was cooled and filtered using Whatman paper No. 1 (Whatman Int. Ltd., Maidstone, U.K). The filtrate obtained was evaporated in the oven at $60^{\circ} \mathrm{C}$ for 72 hours. The extract obtained was stored at $25^{\circ} \mathrm{C}$ in the laboratory.

\subsection{Quantitative Phytochemical Analysis of the Extract}

\subsubsection{Determination of Total Polyphenol Content}

The amount of total polyphenols in the extract was determined using the Singleton and Rossi method (1965). Briefly, $30 \mu \mathrm{L}$ of extract $(1 \mathrm{mg} / \mathrm{mL})$ was added to $1 \mathrm{~mL}$ of the $0.2 \mathrm{~N}$ Folin Ciocalteu reagent. A Spectrophotometer (Genesys 20) was used to measure the absorbance at $750 \mathrm{~nm}$ of the complex formed between Folin and polyphenols after 30 minutes of incubation at room temperature against the blank. Curcumin (0-1000 $\mathrm{mg} / \mathrm{mL}$ ) was used as standard and the result obtained was expressed as equivalent $\mathrm{mg}$ of curcumin per $\mathrm{g}$ of dry matter. 


\subsubsection{Determination of Total Flavonoid Content}

The presence of flavonoids in the extract was assessed according to the procedure described by Aiyegoro \& Okoh (2010). For a $1 \mathrm{~mL}$ extract $(5 \mathrm{mg} / \mathrm{mL}), 1 \mathrm{~mL} 10 \%$ aluminum chloride, $1 \mathrm{~mL}$ potassium acetate $(1 \mathrm{M})$ and $5.6 \mathrm{~mL}$ distilled $\mathrm{H}_{2} \mathrm{O}$ was added and mixed. The mixture was then incubated at room temperature for 30 minutes. A spectrophotometer (Genesys 20) was used to measure the absorbance at $420 \mathrm{~nm}$ against the blank. The standard was catechin $(0-40 \mu \mathrm{g} / \mathrm{mL})$ and the flavonoid concentration was expressed in $\mu \mathrm{g}$ catechin per $\mathrm{g}$ of dry material.

\subsection{Experimentation}

\subsubsection{Food Composition}

Table 1 shows the composition of the diets used in this study.

Table 1. Dietary composition of the normal and atherogenic diet (Ble-Castillo et al., 2012, with some changes)

\begin{tabular}{lll}
\hline Ingredient & \multicolumn{2}{l}{ Composition in g per $100 \mathrm{~g}$ of food } \\
\cline { 2 - 3 } & Normal diet & Atherogenic diet (DESF) \\
\hline Milk & 10 & 10 \\
Fish meal & 10 & 10 \\
Refined palm oil & 10 & 12.5 \\
Margarine & $/$ & 12.5 \\
Sucrose & $/$ & 18 \\
Depulped cornflour & 35 & 18 \\
Wheat flour & 20 & 15 \\
Salt & 1.5 & 1.5 \\
Bone meal & 2.5 & 2.5 \\
Polyvitamins & 1 & 1 \\
Fibers (cellulose) & 1 & 1 \\
Distilled water & 10 & $/$ \\
\hline
\end{tabular}

DESF: a diet enriched with sucrose and fat

The changes made on the composition of the atherogenic diet were a reduction in the proportion of saturated fats, the addition of unsaturated fats, and an increase in the amount of sucrose.

\subsubsection{Animals}

Animals were handled according to the European Union Animal Care (CEE Council 86/609) guideline adopted by the Cameroon National Ethics Committee. Adult male Wistar albino rats of the age range $12-16$ weeks and 200-340 g body weight were maintained at their housing conditions with relative humidity (50\%) at $25^{\circ} \mathrm{C}$ temperature. They were obtained from the Laboratory of Nutrition and Nutritional Biochemistry (LNNB) of the University of Yaounde I and were acclimated for 7 days before used. The animals had free access to water, a normal diet, and were maintained in a 12-hour light/dark cycle.

\subsubsection{Experimental Design}

A total of Twenty-five rats were used. Five of them (210-240 g) constituted the normal group (normal control) and received a normal diet (ND). Twenty (330-340 g) received an atherogenic diet supplemented with fructose at $10 \%(\mathrm{~g} / \mathrm{v})$. They were divided into four groups of 5 rats as follows: untreated group (positive control): DESG + distilled water; treated group 1: atherogenic diet (DESF) $+200 \mathrm{mg} / \mathrm{kg}$ extract; treated group 2: atherogenic diet $(\mathrm{DESF})+400 \mathrm{mg} / \mathrm{kg}$ extract and standard group: atherogenic diet (DESF) + atorvastatin at $5 \mathrm{mg} / \mathrm{kg}$. The administration of the extract and atorvastatin was done daily by gavage using an esophageal probe. The experiment lasted 28 days during which the animals had access to water and the diet ad libitum. Their weight was taken each week, which allowed the calculation of the weight variation according to the following formula:

\subsubsection{Preparation of Samples}

$$
\text { Weight variation }(\%)=\frac{(\text { Final weight }- \text { Initial weight }) \mathrm{g}}{\text { Final weight }(\mathrm{g})} \times 100
$$

At the end of the experiment, the rats were sacrificed by cervical dislocation after slight ether anesthesia. Blood was immediately collected in the EDTA tubes and centrifuged at $3000 \mathrm{rpm}$ for 10 minutes to obtain the plasma. The heart was then collected for the preparation of the $10 \%$ (w/v) homogenate in $\mathrm{NaCl}(0.9 \%)$. Succinctly, the 
organ after sampling was rinsed in sodium chloride $(0.9 \%)$ and then wrung out on filter paper and crushed. The corresponding volume of $\mathrm{NaCl}$ was added and centrifuged at $900 \mathrm{~g}$ for 10 minutes and the supernatant was recovered. Both samples (supernatant and plasma) were aliquot stored at $-20^{\circ} \mathrm{C}$ for biochemical analyses.

\subsection{Determination of Lipid Profile Parameters}

Total cholesterol (TC), triglycerides (TG), and high-density lipoprotein cholesterol (HDL-c) were assessed in plasma using standard chronolab brand assay kits. Low-density lipoprotein cholesterol (LDL-c) and very-low-density lipoprotein cholesterol (VLDL-c) were determined using the formula of Friedewald, Levy \& Friedrickson (1972).

$$
\begin{gathered}
\mathrm{LDL}-\mathrm{c}(\mathrm{mg} / \mathrm{dL})=\mathrm{TC}-\left(\mathrm{HDL}-\mathrm{c}+\frac{\mathrm{TG}}{5}\right) \\
\mathrm{VLDL}-\mathrm{c}(\mathrm{mg} / \mathrm{dL})=\frac{\mathrm{TG}}{5}
\end{gathered}
$$

The concentration of non-HDL cholesterol was calculated using the formula established by Brunzell et al., 2008):

$$
\text { non-HDL-c }(\mathrm{mg} / \mathrm{dL})=[\mathrm{TC}]-[\mathrm{HDL}-\mathrm{c}]
$$

\subsection{Calculation of Insulin Resistance and Atherogenic Indices}

Lipid profile parameters were used to calculate insulin resistance, atherogenic indices cardioprotective index, and vascular protection. Insulin resistance (IR) was assessed using the following formula:

$$
\mathrm{IR}=\frac{[\mathrm{TG}]}{[\mathrm{HDL}-\mathrm{c}]}
$$

The atherogenic index of plasma (AIP), atherogenic coefficient (AC), cardiac risk ratio (CRR), and cardioprotective index (CPI) were calculated as follows.

$$
\begin{array}{cc}
\mathrm{AIP}=\log \left(\frac{[\mathrm{TG}]}{[\mathrm{HDL}-\mathrm{c}]}\right) & (\text { Althunibat } \text { et al.; 2019); } \\
\mathrm{AC}=\frac{([\mathrm{TC}]-[\mathrm{HDL}-\mathrm{c}])}{[\mathrm{HDL}-\mathrm{c}]} & \text { (Althunibat } \text { et al.; 2019); } \\
\mathrm{CRR} 1=\frac{[\mathrm{TC}]}{[\mathrm{HDL}-\mathrm{c}]} ; \mathrm{CRR} 2=\frac{[\mathrm{LDL}-\mathrm{c}]}{[\mathrm{HDL}-\mathrm{c}]} & \text { (Ikewuchi \& Ikewuchi, 2009a, b); } \\
\mathrm{CPI}=\frac{[\mathrm{HDL}-\mathrm{c}]}{[\mathrm{LDL}-\mathrm{c}]} & \text { (Oršoli' } \text { et al., 2014). }
\end{array}
$$

The formula below was used to calculate vascular protection.

$$
\text { Vascular protection }(\%)=\frac{\text { AIP positive control }- \text { AIP treated group }}{\text { AIP positive control }} \times 100
$$

\subsection{Determination of Cardiac Function Parameters}

Plasma and cardiac nitric oxide (NO) was evaluated based on the diazotization reaction (Griess, 1879; Chaea, Lee, Kim \& Bae, 2004) and the activity of cardiac aspartate aminotransferase (ASAT) by that of Reitman \& Frankel (1957).

\subsection{Determination of Hepatic Function Parameters}

Plasma activity of alanine aminotransferase (ALAT) and aspartate aminotransferase (ASAT) was evaluated by the colorimetric method described by Reitman \& Frankel (1957). The determination of total plasma protein levels was carried out using the method of Lowry, Rosebrough, Farr \& Randall (1951).

\section{Statistical Analysis}

The results obtained were expressed as mean \pm standard error on the mean. The values were analyzed with the statistical package for social science (SPSS) software version 20.0. The ANOVA test was used for the descriptive analysis and the comparison between the groups was performed by the post hoc LSD test. The difference in significance was noted at $\mathrm{p}<0.05$ and $\mathrm{p}<0.001$. The excel spreadsheet was been used to plot the graph. 


\section{Results}

\subsection{The Polyphenol Content of the Extract}

The total polyphenol and flavonoid content of aqueous bark extract of D. microcarpum is shown in table 2 .

Table 2. Total polyphenol and flavonoid content of the aqueous bark extract of D. microcarpum

\begin{tabular}{ll}
\hline Detarium microcarpum & Aqueous bark extract \\
\hline Total polyphenols (mg ECu/g of DM) & $777.50 \pm 9.14$ \\
Total flavonoids ( $\mu \mathrm{g} \mathrm{d}$ 'EC/g of DM) & $53.62 \pm 1.63$ \\
\hline
\end{tabular}

$\mathrm{ECu}$ : Curcumin equivalent, EC: Catechin equivalent; DM: dry material.

\subsection{Effect of Oral Administration of Extract on the Body Weight of Rats}

An increase in weight was observed in both control groups (Figure 1). However, administration of aqueous bark extract at doses of $200 \mathrm{mg} / \mathrm{kg} / \mathrm{day}$ and $400 \mathrm{mg} / \mathrm{kg} /$ day and atorvastatin at $5 \mathrm{mg} / \mathrm{kg} /$ day respectively limited weight gain in the different treated groups. This effect was more pronounced in the group treated with the 200 $\mathrm{mg} / \mathrm{kg} /$ day extract.

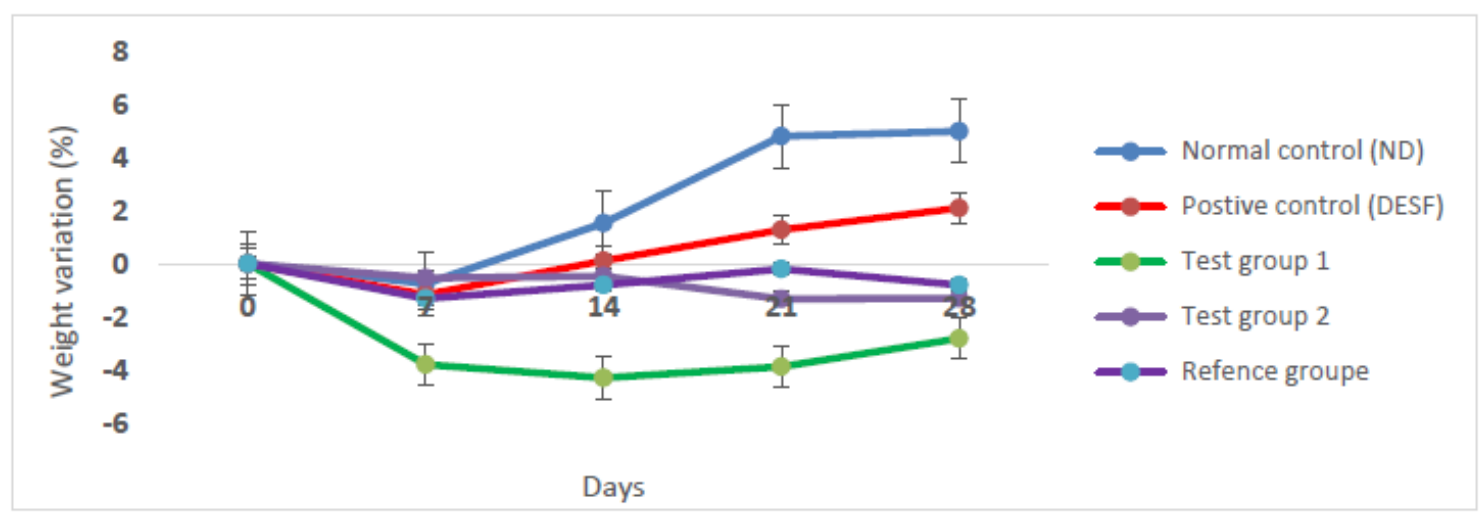

Figure 1. Influence of administration of the aqueous extract of Detarium microcarpum bark on the weight variation of experimental rats

$\mathrm{n}=5$; ND : normal diet ; DESF : diet enriched in sugar and fat ; Treated group $1: \mathrm{DESF}+200 \mathrm{mg} / \mathrm{kg} / \mathrm{day}$ extract ; Treated group $2: \mathrm{DESF}+400 \mathrm{mg} / \mathrm{kg} /$ day extract ; Standard group : DESF $+5 \mathrm{mg} / \mathrm{kg} /$ day atorvastatin

\subsection{Effect of Detarium microcarpum Extract on Plasma Lipid Profile}

An increase was observed in TG, TC, VLDL-c, non-HDL-c and a decrease in HDL-c in the untreated group (positive control) compared to the normal control group $(\mathrm{p}<0.05)$ (table 3). Oral administration of the extract at doses of $200 \mathrm{mg} / \mathrm{kg}$ body weight and $400 \mathrm{mg} / \mathrm{kg}$ body weight limited the increase in TG, TC, VLDL-c, LDL-c, and non-HDL-c compared to the untreated group $(\mathrm{p}<0.001)$. The extract at both doses resulted in an increase in HDL-c ( $\mathrm{p}<0.001)$.

Table 3. Influence of extract on plasma levels of triglyceride, total cholesterol, very-low-density lipoproteins cholesterol, low-density lipoproteins-cholesterol, high-density lipoproteins-cholesterol (HDL) and non-HDL-c

\begin{tabular}{llllll}
\hline & $\begin{array}{l}\text { Normal } \\
\text { control (ND) }\end{array}$ & $\begin{array}{l}\text { Positive } \\
\text { control (DESF) }\end{array}$ & $\begin{array}{l}\text { Treated } \\
\text { group 1 }\end{array}$ & $\begin{array}{l}\text { Treated } \\
\text { group 2 }\end{array}$ & $\begin{array}{l}\text { Standard } \\
\text { group }\end{array}$ \\
\hline TG & $31.13 \pm 1.40^{\mathrm{a}}$ & $129.90 \pm 0.40^{\mathrm{b}}$ & $77.61 \pm 0.60^{\mathrm{c}^{*}}$ & $85.65 \pm 0.04^{\mathrm{d}^{*}}$ & $62.69 \pm 4.48^{\mathrm{e} *}$ \\
TC & $65.07 \pm 5.30^{\mathrm{a}}$ & $92.07 \pm 0.25^{\mathrm{b}}$ & $91.92 \pm 0.36^{\mathrm{b}}$ & $92.07 \pm 0.60^{\mathrm{b}}$ & $65.43 \pm 4.48^{\mathrm{da}}$ \\
VLDL-c & $6.23 \pm 0.28^{\mathrm{a}}$ & $25.98 \pm 0.08^{\mathrm{b}}$ & $15.52 \pm 0.12^{\mathrm{c}^{*}}$ & $17.13 \pm 0.01^{\mathrm{cd}}$ & $12.53 \pm 0.90^{\mathrm{e}^{*}}$ \\
LDL-c & $30.31 \pm 4.60^{\mathrm{a}}$ & $49.55 \pm 0.41^{\mathrm{b}}$ & $31.02 \pm 0.99^{\mathrm{a}^{*}}$ & $21.17 \pm 0.94^{\mathrm{c}^{*}}$ & $17.53 \pm 1.31^{\mathrm{d}^{*}}$ \\
HDL-c & $28.53 \pm 0.60^{\mathrm{a}}$ & $16.54 \pm 0.41^{\mathrm{b}}$ & $45.38 \pm 0.99^{\mathrm{c}^{*}}$ & $53.77 \pm 0.94^{\mathrm{d}^{*}}$ & $35.37 \pm 0.91^{\mathrm{e}^{*}}$ \\
non-HDL-c & $36.75 \pm 4.70^{\mathrm{a}}$ & $75.53 \pm 0.16^{\mathrm{b}}$ & $46.54 \pm 0.63^{\mathrm{c}^{*}}$ & $38.30 \pm 0.34^{\mathrm{d}^{*}}$ & $30.06 \pm 3.56^{\mathrm{a}^{*}}$ \\
\hline
\end{tabular}

$\mathrm{n}=5$; ND : normal diet ; DESF : diet enriched in sugar and fat ; Treated group $1: \mathrm{DESF}+200 \mathrm{mg} / \mathrm{kg} / \mathrm{day}$ extract ; Treated group $2: \mathrm{DESF}+400 \mathrm{mg} / \mathrm{kg} /$ day extract ; Standard group : DESF $+5 \mathrm{mg} / \mathrm{kg} /$ day atorvastatin ; TG ; triglyceride ; TC : total cholesterol ; VLDL : very low density lipoproteins-cholesterol ; LDL : low density 
lipoproteins-cholesterol ; HDL : high density lipoproteins-cholesterol ; $\mathrm{c}$ : choleterol ; the assigned values of the alphabetic letters are significantly different $(\mathrm{p}<0.05)$; * represents the difference in significance $(\mathrm{p}<0.001)$ between the positive control and the treated groups.

\subsection{Effect of the Extract on Insulin Resistance and Atherogenic Risk}

Table 4 presents data on the effects of the extract on IR, CRR, AC, AIP, CPI, and vascular protection (\%). IR, CRR, AC and AIP were higher in rats of the positive control compared to the normal control groups $(\mathrm{p}<0.001)$. CPI was low in positive control than normal control groups $(\mathrm{p}<0.001)$. On the other hand, the administration of the extract at two doses and atorvastatin resulted a significant decrease in IR, CRR, AC and AIP, in the treated compared to positive control ( $\mathrm{p}<0.001)$. While, the CPI was higher in threated groups $(\mathrm{p}<0.001)$. The percentage of vascular protection obtained was higher in the group treated with $400 \mathrm{mg} / \mathrm{kg}$ extract body weight compared to the group treated with $200 \mathrm{mg} / \mathrm{kg}$ extract and $5 \mathrm{mg} / \mathrm{kg}$ atorvastatin.

Table 4. Effect of the extract on insulin resistance, atherogenic indices, and vascular protection

\begin{tabular}{llllll}
\hline & $\begin{array}{l}\text { Normal } \\
\text { control (ND) }\end{array}$ & $\begin{array}{l}\text { Positive } \\
\text { control (DESF) }\end{array}$ & $\begin{array}{l}\text { Treated } \\
\text { group 1 }\end{array}$ & $\begin{array}{l}\text { Treated } \\
\text { group 2 }\end{array}$ & $\begin{array}{l}\text { Standard } \\
\text { group }\end{array}$ \\
\hline $\mathrm{IR}$ & $1.09 \pm 0.03^{\mathrm{a}}$ & $7.88 \pm 0.17^{\mathrm{b}}$ & $1.71 \pm 0.02^{\mathrm{c}^{*}}$ & $1.59 \pm 0.03 \mathrm{~d}^{\mathrm{c}^{*}}$ & $1.76 \pm 0.08^{\mathrm{ad} \mathrm{d}^{*}}$ \\
$\mathrm{CRR}_{1}$ & $2.27 \pm 0.14^{\mathrm{a}}$ & $5.58 \pm 0.12^{\mathrm{b}}$ & $2.03 \pm 0.04^{\mathrm{c}^{*}}$ & $1.70 \pm 0.03^{\mathrm{a}^{*}}$ & $1.84 \pm 0.08^{\mathrm{c}^{*}}$ \\
$\mathrm{CRR}_{2}$ & $1.06 \pm 0.14^{\mathrm{a}}$ & $2.99 \pm 0.03^{\mathrm{b}}$ & $0.68 \pm 0.01^{\mathrm{c}^{*}}$ & $0.39 \pm 0.01^{\mathrm{dc}}$ & $0.49 \pm 0.02^{\mathrm{ec}^{*}}$ \\
$\mathrm{AC}$ & $1.27 \pm 0.14^{\mathrm{a}}$ & $4.58 \pm 0.12^{\mathrm{b}}$ & $1.02 \pm 0.04^{\mathrm{c}^{*}}$ & $0.71 \pm 0.03^{\mathrm{d} *}$ & $0.84 \pm 0.08^{\mathrm{e}^{*}}$ \\
$\mathrm{AIP}$ & $0.04 \pm 0.01^{\mathrm{a}}$ & $0.90 \pm 0.01^{\mathrm{b}}$ & $0.23 \pm 0.01^{\mathrm{a}^{*}}$ & $0.20 \pm 0.01^{\mathrm{a}^{*}}$ & $0.24 \pm 0.02^{\mathrm{c}^{*}}$ \\
CPI & $1.04 \pm 0.14^{\mathrm{a}}$ & $0.45 \pm 0.01^{\mathrm{b}}$ & $1.47 \pm 0.01^{\mathrm{c}^{*}}$ & $2.56 \pm 0.07^{\mathrm{d}^{*}}$ & $2.06 \pm 0.10^{\mathrm{e}^{*}}$ \\
$\%$ protection & - & - & 74.44 & 77.78 & 73.33 \\
\hline
\end{tabular}

$\mathrm{n}=5$; ND : normal diet ; DESF : diet enriched in sugar and fat ; Treated group $1: \mathrm{DESF}+200 \mathrm{mg} / \mathrm{kg} / \mathrm{day}$ extract ; Treated group $2: \mathrm{DESF}+400 \mathrm{mg} / \mathrm{kg} /$ day extract ; Standard group : DESF $+5 \mathrm{mg} / \mathrm{kg} /$ day atorvastatin ; CRR : cardiac risk ratio ; AC : atherogenic coefficient; AIP : atherogenic index of plasma; IR : insulin resistance ; CPI : cardiprotective index; The assigned values of the alphabetic letters are significantly different $(p<0.05) *$ represents the difference in significance $(p<0.001)$ between the positive control and the treated groups.

\subsection{The Ability of the Extract to Improve Cardiac Function}

Plasma nitric oxide (NO) in rats in the groups receiving aqueous bark extract of D. microcarpum (treated group) at both doses was significantly lower compared to positive control $(\mathrm{p}<0.05)$ (Table 5). However, in the heart, NO was higher in the treated groups than in the untreated group. The same observation was made after the evaluation of the activity of plasma aspartate aminotransferase (ASAT). In treated groups, there was a significant increase ( $\mathrm{p}<0.05 ; \mathrm{p}<0.001)$ in cardiac NO, ASAT and significant decrease $(\mathrm{p}<0.05 ; \mathrm{p}<0.001)$ in plasma NO.

Table 5. Effect of the extract on cardiac, plasma nitric oxide levels and cardiac activity of aspartate aminotransferase

\begin{tabular}{llllll}
\hline & $\begin{array}{l}\text { Normal } \\
\text { control (ND) }\end{array}$ & $\begin{array}{l}\text { Positive } \\
\text { control (DESF) }\end{array}$ & $\begin{array}{l}\text { Treated } \\
\text { group 1 }\end{array}$ & $\begin{array}{l}\text { Treated } \\
\text { group 2 }\end{array}$ & $\begin{array}{l}\text { Standard } \\
\text { group }\end{array}$ \\
\hline NO (Cardiac) & $42.72 \pm 0.93^{\mathrm{a}}$ & $33.67 \pm 0.20^{\mathrm{b}}$ & $36.15 \pm 0.64^{\mathrm{c}^{*}}$ & $38.24 \pm 0.44^{\mathrm{d}^{*}}$ & $37.54 \pm 0.62^{\mathrm{e}^{*}}$ \\
NO (Plasma) & $32.69 \pm 1.94^{\mathrm{a}}$ & $83.56 \pm 2.68^{\mathrm{b}}$ & $45.75 \pm 0.70^{\mathrm{c}}$ & $36.94 \pm 0.46^{\mathrm{ad}} \mathrm{d}^{*}$ & $23.95 \pm 0.34^{\mathrm{e}^{*}}$ \\
ASAT (Cardiac) & $49.05 \pm 0.39^{\mathrm{a}}$ & $41.66 \pm 0.51^{\mathrm{b}}$ & $44.17 \pm 0.46^{\mathrm{c}}$ & $43.33 \pm 0.47^{\mathrm{d}}$ & $44.05 \pm 0.58^{\mathrm{e}}$ \\
\hline
\end{tabular}

$\mathrm{n}=5$; ND : normal diet ; DESF : diet enriched in sugar and fat ; Treated group $1: \mathrm{DESF}+200 \mathrm{mg} / \mathrm{kg} / \mathrm{day}$ extract ; Treated group $2:$ DESF $+400 \mathrm{mg} / \mathrm{kg} /$ day extract ; Standard group : DESF $+5 \mathrm{mg} / \mathrm{kg} /$ day atorvastatin ; NO : nitric oxide; ASAT: aspartate aminotransferase; the assigned values of the alphabetic letters are significantly different $(\mathrm{p}<0.05) ; *$ represents the difference in significance $(\mathrm{p}<0.001)$ between the positive control and the treated groups.

\subsection{The Ability of Extracts to Improve Liver Function}

The results of the plasma assessment of transaminase activity (AST and ALT) and total protein levels are presented in Table 6 . In the groups treated with the extract, there was a decrease in total proteins compared to the untreated group ( $<$ 0.001). The activity of ALAT and ASAT in the group receiving the extract at $200 \mathrm{mg} / \mathrm{kg}$ 
body weight was low compared to the untreated group. While the activity of both transaminases was higher in the group treated with $400 \mathrm{mg} / \mathrm{kg}$ body weight. In the standard group, these activities were lower compared to the untreated group $(\mathrm{p}<0.001)$.

Table 6. Effect of the extract on plasma activity of alanine aminotransferase, aspartate aminotransferase, and total protein levels

\begin{tabular}{llllll}
\hline & $\begin{array}{l}\text { Normal } \\
\text { control (ND) }\end{array}$ & $\begin{array}{l}\text { Positive } \\
\text { control (DESF) }\end{array}$ & $\begin{array}{l}\text { Treated } \\
\text { group 1 }\end{array}$ & $\begin{array}{l}\text { Treated } \\
\text { group 2 }\end{array}$ & $\begin{array}{l}\text { Standard } \\
\text { group }\end{array}$ \\
\hline ALAT & $96.25 \pm 2.98^{\mathrm{a}}$ & $275.73 \pm 17.84^{\mathrm{b}}$ & $263.00 \pm 7.72^{\mathrm{b}}$ & $300.19 \pm 40.17^{\mathrm{db}}$ & $54.13 \pm 5.48^{\mathrm{c}^{*}}$ \\
ASAT & $80.53 \pm 1.91^{\mathrm{a}}$ & $139.05 \pm 16.05^{\mathrm{b}}$ & $133.31 \pm 5.21^{\mathrm{cb}}$ & $148.70 \pm 9.41^{\mathrm{db}}$ & $75.95 \pm 13.50^{\mathrm{a}^{*}}$ \\
Total protein & $25.80 \pm 2.23^{\mathrm{a}}$ & $31.44 \pm 0.25^{\mathrm{b}}$ & $21.06 \pm 0.28^{\mathrm{c}^{*}}$ & $22.17 \pm 0.39^{\mathrm{d}^{*}}$ & $29.33 \pm 1.30^{\mathrm{ae}}$ \\
\hline
\end{tabular}

$\mathrm{n}=5$; ND : normal diet ; DESF : diet enriched in sugar and fat ; Treated group $1: \mathrm{DESF}+200 \mathrm{mg} / \mathrm{kg} / \mathrm{day}$ extract ; Treated group $2:$ DESF $+400 \mathrm{mg} / \mathrm{kg} /$ day extract ; Standard group : DESF $+5 \mathrm{mg} / \mathrm{kg} /$ day atorvastatin ; ALAT : alanine aminotransferase; ASAT : aspartate aminotransferase ; the assigned values of the alphabetic letters are significantly different $(p<0.05) *$ represents the difference in significance $(p<0.001)$ between the positive control and the treated groups.

\section{Discussion}

Insulin resistance is at the center of several metabolic disorders. These include obesity, type 2 diabetes, dyslipidemia, and non-alcoholic fatty liver disease, all important risk factors for cardiovascular disease (Kato et al., 2015; Oseini \& Sanyal, 2016). The objective of this study was to evaluate the effect of the aqueous extract of Detarium microcarpum (D. microcarpum) bark on the lipid profile, atherogenicity index, markers of cardiac and hepatic function in rats fed on an atherogenic diet (DESF). Preliminary results on the phenolic compound composition of the extract revealed the presence of total polyphenols and flavonoids (Table 2). The values obtained in this work are different from those obtained by Hama, Ouedraogo \& Adama (2019) who worked on the antioxidant activity of méthanolic extracts from various organs of D. microcarpum. The difference in solubility of polyphenols in the solvent system (Ghedadba, Bousselsela, Hambaba, Benbia \& Mouloud, 2014); the environmental conditions of the plant (Falleh et al., 2008), and the extraction method used to justify the variability observed. The existence of these phenolic compounds would suggest that the extract has hypolipidemia, antioxidant, anti-atherogenic, anti-inflammatory potential and will have the ability to improve endothelial function and limit cardiovascular risk. Thus, the preventive effect of $D$. microcarpum extract on certain metabolic and physiological disorders was investigated for 28 days in Wistar rats. The rats fed on a normal diet had a greater weight variation than those receiving DESF alone (figure 1). It was $5.46 \%$ and $2.15 \%$ for the normal and untreated groups, respectively. This result shows a low dietary intake of untreated rats that would be justified by a decrease in appetite following a change in diet type. However, a high-calorie diet, although poorly consumed, leads to the development of metabolic disorders associated with chronic diseases. Jin, Yi \& Mei (2013), showed that rodents fed a high-fat diet develop insulin resistance, dyslipidemia, and hepatic steatosis. Concomitant administration of DESF supplemented with fructose and extract at doses of $200 \mathrm{mg} / \mathrm{kg}$ (treated group 1) and $400 \mathrm{mg} / \mathrm{kg}$ (treated group 2) and atorvastatin at $5 \mathrm{mg} / \mathrm{kg}$ (reference) limited the weight gain of animals in these groups with respective percentage changes of $-2.81 \%$; - $0.97 \%$ and $-0.80 \%$ compared to the untreated group. The polyphenols content in the extract limit rat weight gain by inhibiting lipid digestion, and/or the absorption of their digestion products leading to an increase in their fecal excretion. Polyphenols such as catechin reduce weight gain by stimulating energy expenditure at the cellular level by increasing lipolytic protein expression or by inhibiting lipogenesis through the suppression of fatty acid synthase expression (Yamashita et al., 2007; Kyung, Myoung, Keunae, \& Hwang, 2011).

Dyslipoproteinemias are strongly associated with the development of atherosclerosis and its complications (Mulvihill, Burke \& Huff, 2016, Bergheanu, Bodde \& Jukema, 2017). Thus, all compounds with lipid-lowering and anti-obesogenic properties limit the occurrence of atherosclerosis and its clinical complications like cardiopathy and hepatopathy. In general, the effect of the extract on plasma lipid levels showed a decreased of TG, TC, LDL-c, non-HDL-c, VLDL-c and increased HDL-c compared to the positive control $(\mathrm{p}<0.001)$ (table 3). This lipid-lowering potential (especially low levels of LDL-c and non-HDL-c) of the extract reflects its ability to prevent atherogenic risk in rats and associated vascular and tissue complications. The evaluation of the atherogenic index and the IR was therefore correlated with this ability of the extract to lower plasma lipid concentrations. Significant low $(\mathrm{p}<0.001) \mathrm{IR}, \mathrm{CRR}, \mathrm{AC}$, and AIP values were observed in the groups receiving the extract (Table 4), showing its anti-atherogenic potential. This protective power of extract against 
atherogenesis induced by DESF is justified by the achievement of high vascular protection and CPI. The indices (IR, CRR, AC, AIP) are useful for assessing the risk of developing CVD, the more accurate the increase, the higher the risk of CVD (Oršoli et al., 2019). On the other hand, the CPI reflects the cardioprotective potential of a compound. The compound is more effective when the index is higher. The presence of polyphenols/flavonoids in $D$. microcarpum extract gives it the ability to normalize plasma lipids, reduce the onset of coronary heart disease, and the accumulation of liver fat as observed. Middleton, Kandaswami \& Theoharides (2000), showed that citrus flavonoids lowered LDL and TG cholesterol levels in normolipidemic and hyperlipidemic rats. These phenolic compounds used for the prevention/treatment of cardiovascular diseases and their related complications act at various levels. Notably, the inhibition of lipid-digesting enzymes, stimulation of lecithin acyl cholesterol transferase expression (Okafor, Ezeanyika, Nkwonta \& Okonkwo, 2015). Flavonoids inhibit the expression of cholesteryl ester transport protein (CETP) which reduces plasma LDL-c levels (Kuivenhoven et al., 1997). This decrease in plasma LDL-c is associated with increased expression of LDL receptors (LDLR) under the control of sterol regulatory element-binding protein-2 (SREBP-2) (Soutar \& Naoumova, 2007; You, Su \& Zhou, 2008). LDLR is involved in the lysosomal degradation of LDL-c. Flavonoids also lower plasma cholesterol levels by inhibition of acyl CoA cholesterol acyltransferases (ACATs) resulting in inhibition of intestinal cholesterol absorption and hepatic production of VLDL (Keti, Ketan, Randolph, Arroo, Roberta \& Matteo, 2017). Studies of Masao et al. (2009); Saranan et al. (2009) and Nagendra, Rajasekhar \& Raghn, (2017) on pine, Terminalia arjuna, Cinnamomum zeylanicum barks respectively, have also shown beneficial effects on lowering weight gain, preventing dyslipidemia and reducing atherogenicity. Besides, all these barks have shown a protective effect of the aorta against atherosclerotic lesions.

Endothelial dysfunction associated with the overproduction of reactive oxygen species (ROS) is responsible for the onset of atherosclerosis and tissue complications. The key event is vascular production of ROS such as superoxide anion $\left(\mathrm{O}^{2-}\right)$, catalyzed by NADPH oxidase (NOX) (Griendling, Sorescu, \& Ushio-Fukai, 2000). Our results reveal the beneficial effects of $D$. microcarpum on the improvement of endothelial and hepatic function (Table 5 and 6). A decrease in the bioavailability of cardiac NO is indicative of possible vasoconstriction, while an increase in cardiac NO is beneficial for vascular health. Thus, the high level of NO observed in this study is thought to result from the activation of the protein kinase B (Akt) pathway, which by phosphorylation of the endothelial nitric oxide synthase (eNOS) leads to NO production. Rocha et al (2019) showed that the leptin/Akt/eNOS signaling pathway is associated with this NO production. Also, polyphenols by inhibition of NOX limit the production of the $\mathrm{O}^{2-}$, which, by action with $\mathrm{NO}$, forms the highly reactive peroxynitrite ion (ONOO-) (Tong, Du-Ok, Bo-Sup, Kyung-Sik \& Seong-Gook, 2015). This compound with a high oxidative power leads to an alteration of the tissue membranes. In plasma, the significant low activity of ALAT, ASAT, low level of NO, and total proteins obtained thus reflects the capacity of the extract to protect the liver and heart from oxidative changes associated with a hyperproduction of ROS. Hama, Ouedraogo \& Adama (2019) have shown that $D$. microcarpum stem bark can trap free radicals and complex metals. This activity would, therefore, explain the plant's protective power against tissue damage caused by excessive ROS production, as observed in this work.

\section{Conclusion}

The results of this study revealed the ability of the stem bark aqueous extract of D. microcarpum due to the presence of polyphenols to regulate plasma lipid/lipoprotein levels (TC, TG, LDL-c, VLDL-c, HDL-c, and non-HDL-c) and to limit weight gain in rats. D. microcarpum significantly reduced atherogenic risk (AIP, CRR, AC), insulin resistance index (IR), and increased cardioprotection index (CPI). In general, this plant improved cardiac and liver function, hence its cardioprotective and hepatoprotective potential. In addition to this work, further studies need to be carried out on transgenic models of cardiovascular disease and monocytes in culture to elucidate the precise mechanism of action of the extract.

\section{Conflicts of Interest}

The authors declare that they have no conflict of interest.

\section{References}

Adama, O. (1997). L'effet de la coupe de Detarium microcarpum Guill, \& Perr. sur la régénération de la végétation dans la forêt classée de Nazinon. Mémoire d'ingenieur, Université de Ouagadougou, (Burkina Fasso), pp. 108.

Aiyegoro, O., \& Okoh, A. (2010). Preliminary phytochemical screening and In vitro antioxidant activities of the aqueous extract of Helichrysum longifolium DC. BMC Complementary and Alternative Medicine, 10, 21. https://dx.doi.org/10.1186/1472-6882-10-21 
Al Qahtany, H., Faisal, H., Hawra, A., Ahmed, A., Haifa, S., Ala'a, M., ... Mishael, T. (2018). Atherosclerosis: Pathophysiology and Management. The Egyptian Journal of Hospital Medicine, 70, 82-87. https://doi.org/10.12816/0042966

Althunibat, O., Al Hroob, A., Abukhalil, M., Germoush, M., Bin-Jumah, M., \& Mahmoud, A. (2019). Fisetin ameliorates oxidative stress, inflammation, and apoptosis in diabetic cardiomyopathy. Life Science, 15(221), 83-92. https://doi.org/10.1016/j.lfs.2019.02.017

Amiot, M., Riva, C., \& Vinet, A. (2016). Effects of dietary polyphenols on metabolic syndrome features in humans: a systematic review. Obesity Reviews, 17(7), 573-586. https://doi.org/10.1111/obr.12409

Aziz, M., \& Yadav, K. (2016). Pathogenesis of Atherosclerosis A Review. Medical and Clinical Reviews, 2(3), 1-6. https://doi.org/10.21767/2471-299X.1000031

Bergheanu, S., Bodde, M., \& Jukema J. (2017). Pathophysiology and treatment of atherosclerosis Current view and future perspective on lipoprotein modification treatment. Netherlands Heart Journal, 25, 231-242. https://doi.org/10.1007/s12471-017-0959-2

Ble-Castillo, J., Aparicio-Trapala, M., Juárez-Rojop, E., Torres-Lopez, J., Mendez, J., Aguilar-Mariscal, H., ... Diaz-Zagoya, J. (2012). Differential Effects of High-Carbohydrate and High-Fat Diet Composition on Metabolic Control and Insulin Resistance in Normal Rats. International Journal of Environmental Research and Public Health, 9, 1663-1676. https://doi.org/10.3390/ijerph9051663

Brunzell, J., Davidson, M., Furberg, C., Goldberg, R., Howard, B., Stein, J., \& Witztum, J. (2008). Lipoprotein management in patients with cardiometabolic risk: consensus conference report from the American Diabetes Association and the American College of Cardiology Foundation. Journal of the American College of Cardiology, 51, 1512-24. https://doi.org/10.1016/j.jacc.2008.02.034

Chaea, Y., Lee, M., Kim, W., \& Bae, H. (2004). Protection of insulin-secreting cells from nitric oxide-induced cellular damage by crosslinked hemoglobin. Biomaterials, 25, 843-850. https://doi.org/10.1016/S0142-9612(03)00605-7

Falleh, H., Ksouri, R., Chaieb, K., Karray-Bouraoui N., Trabelsi, N., Boulaaba, M., \& Abdelly, C., (2008). Phenolic composition of Cynara cardunculus L. organs, and their biological activities, Comptes Rendus Biologies, 331, 372-379. https://doi.org/10.1016/j.crvi.2008.02.008

Friedewald, W., Levy, R., \& Friedrickson, D. (1972). Estimation of the concentration of low-density lipoprotein cholesterol in plasma, without the use of the preparative ultracentrifuge. Clinical Chemistry, 18(6), 499-502. https://doi.org/10.1093/clinchem/18.6.499

Ghedadba, N., Bousselsela, H., Hambaba, L., Benbia, S., \& Mouloud, Y. (2014). Évaluation de l“eactivité antioxydante et antimicrobienne des feuilles et des sommités fleuries de Marrubium vulgare $\mathrm{L}$. Phytothérapie, 12, 15-24. https://doi.org/10.1007/s10298-014-0832-z

Griendling, K., Sorescu, D., \& Ushio-Fukai, M. (2000). NADPH oxidase: Role in cardiovascular biology and disease. Circulation Research, 86, 494-501. https://doi.org/10.1161/01.res.86.5.494

Griess, P. (1879). Bemerkungen zu der abhandlung der H.H. Weselsky und Benedikt "Ueber einige azoverbindungen. Chemische Berichte, 12(1), 426-428. https://doi.org/10.1002/cber.187901201117

Habauzit, V., \& Morand, C. (2012). Evidence for a protective effect of polyphenols-containing foods on cardiovascular health: an update for clinicians. Therapeutic Advances in Chronic Disease, 3(2), 87-106. https://doi.org/10.1177/2040622311430006

Hama, H., Ouedraogo, B., \& Adama, R. (2019). Activité Antioxydante des extraits méthanoliques de differents organes de Detarium microcarpum Guill. \& Perr. European Scientific Journal, 15(12), 159-171. https://doi.org/10.19044/esj.2019.v15n12p159

Ikewuchi, J., \& Ikewuchi, C. (2009a). Alteration of plasma lipid profiles and atherogenic indices by Stachytarpheta jamaicensis L. (Vahl). Biochemistry, 21(2), 71-7. https://dx.doi.org/10.4314/biokem.v21i2.56473

Ikewuchi, J., \& Ikewuchi, C. (2009b). Alteration of plasma lipid profile and atherogenic indices of cholesterol loaded rats by Tridax procumbens Linn: Implications for the management of obesity and cardiovascular diseases. Biochemistry, 21(2), 95-9. https://dx.doi.org/10.4314/biokem.v2li2.56477

Jin, D., Yi, X., \& Mei, X. (2013). Anti-obesity and lipid-lowering effects of theaflavins on high fat diet-induced obese rats. Journal of Functional Foods, 5(3), 1142-1150. https://doi.org/10.1016/j.jff.2013.03.011 
Kato, K., Takeshita, Y., Misu, H., YohZen, Kaneko, S., \& Takamura, T. (2015). Liver steatosis is associated with insulin resistance in skeletal muscle rather than in the liver in Japanese patients with non-alcoholic fatty liver disease. Journal of Diabetes Investigation, 6, 158-163. https://doi.org/10.1111/jdi.12271

Keti, Z., Ketan, R., Randolph, R., Arroo, J., Roberta, B., \& Matteo, M. (2017). Flavonoids and Their Metabolites: Prevention in Cardiovascular Diseases and Diabetes. Diseases, 5(19), 1-18. https://doi.org/10.3390/diseases5030019

Kuivenhoven, J., Pritchard, H., Hill, J., Frohlich, J., Assmann, G., \& Kastelein, J. (1997). The molecular pathology of lecithin: Cholesterol acyltransferase (LCAT) deficiency syndromes. Journal of Lipid Research, 38, 191-205.

Kyung, J., Myoung, S., Keunae, J., \& Hwang, J. (2011). Piperidine alkaloids from Piper retrofractum Vahl. protect against high-fat diet-induced obesity by regulating lipid metabolism and activating AMP-activated protein kinase. Biochemical and Biophysical Research Communications, 411(1), 219-225. https://doi.org/10.1016/j.bbrc.2011.06.153

Lowry, O., Rosebrough, N., Farr, A., \& Randall, R. (1951). Protein measurement with the Folin phenol reagent. Journal of Biological Chemistry, 193(1), 265-75.

Nagendra, N., Rajasekhar, C., \& Raghu, J. (2017). Anti-atherosclerotic potential of aqueous extract of Cinnamomum zeylanicum bark against glucocorticoid-induced atherosclerosis in Wistar rats. Journal of Clinical and Diagnostic Research, 11(5), 11-23. https://doi.org/10.7860/JCDR/2017/23910.9864

Masao, S., Yasuna, Y., Hiromi, M., Sawako, N., Tomoyasu, K., Motoya, I., \& Katsumi I. (2009). Dietary Pine bark extract reduces atherosclerotic lesion development in male apo E-deficient mice by lowering the serum cholesterol level. Bioscience, Biotechnology, and Biochemistry, 73(6), 1314-1317. https://doi.org/10.1271/bbb.80838

Middleton, E., Kandaswami, C., \& Theoharides, T. (2000). The Effects of Plant Flavonoids on Mammalian Cells: Implications for Inflammation, Heart Disease, and Cancer. Pharmacological Reviews, 52, 673-751. Retrieved from https://www.pharmrev.org

Morand, C., \& Milenkovic, D. (2014). Polyphénols et santé vasculaire: mise en évidence du rôle direct des polyphénols dans les effets bénéfiques des agrumes dans la protection vasculaire. Innovations Agronomiques, 42, 47-62.

Mulvihill E., Burke A., \& Huff. M. (2016). Citrus Flavonoids as Regulators of Lipoprotein Metabolism and Atherosclerosis. Annual Review of Nutrition, 13(58), 1-25. https://doi.org/10.1146/annurev-Nutr-071715-050718

Oibiokpa, F., Godwin, I., Abubakar, N., \& Kudirat, O. (2014). Nutritional composition of Detarium microcarpum fruit. African Journal of food science, 8(6), 342-350. https://doi.org/10.5897/JFS2014.1161

Okafor, O., Ezeanyika, C., Nkwonta, G., \& Okonkwo, C. (2015). Plasma Lipid Profiles and Atherogenic indices of rats fed raw and processed jack fruit (Artocarpus heterophyllus) seeds diets at different concentrations. 9(8), 750-754.

Oršoli, N., Landeka, I., Điki'c, D., Rogi'c, D., Odeh, D., Balta, V., Junakovi'c, K., Terzi'c, S., \& Jutri'c, D. (2019). Effect of propolis on diet-induced hyperlipidemia and atherogenic indices in mice. Antioxidants, 8(156), 1-22. https://doi.org/10.3390/antiox8060156

Oršoli'c, N., Goluža, E., Diki’c, D., Lisi`ci'c, D., Sašilo, K., Rođak, E., Jelěc, Ž., Lazarus, M., \& Orct, T. (2014). Role of flavonoids on oxidative stress and mineral contents in the retinoic acid-induced bone loss model of rat. European Journal of Nutrition, 53, 1217-1227. https://doi.org/10.1007/s00394-013-0622-7

Oseini, A., \& Sanyal, A. (2017). Therapies in non- alcoholic steatohepatitis (NASH). Liver International, 37(1), 97-103. https://doi.org/10.1111/liv.13302

Prasad, G. J., Prakash, G. C., Shashikant, C. D., Sonal, R. B., Priti, S. T., \& Ram, S. S. (2014). Therapeutic approaches to drug targets in atherosclerosis. Saudi Pharmaceutical Journal, 22, 179-190. https://dx.doi.org/10.1016/j.jsps.2013.04.005

Reitman, S., \& Frankel, S. (1957). A colorimetric method for the determination of serum glutamic oxalacetic and glutamic pyruvic transaminases. American Journal of Clinical Pathology, 28(1), 56-63. https://doi.org/10.1093/ajcp/28.1.56

Rocha, V., Claudio, E., Vitor, L., Cordeiro, J., Domingos, F., Márcia, R., ... André, S. (2019). High-fat 
diet-induced obesity model does not promote endothelial dysfunction via increasing Leptin/Akt/eNOS signaling. Frontiers in Physiology, 10(268), 1-10. https://doi.org/10.3389/fphys.2019.00268

Sani, A., Agunu, A., Danmalam, U., \& Ibrahim H. (2014). Pharmacognostic Studies of the Stem Bark of Detarium Microcarpum Guill. and Perr. (Fabaceae). Natural Products Chemistry \& Research, S1, 004. https://doi.org/10.4172/2329-6836.S1-004

Saravanan, S., Ramachandran, S., Suja, R., Subasini, U., Rajamanickam, V., \& Prasad, G. (2009). Anti-atherogenic activity of ethanolic fraction of Terminalia arjuna Bark on hypercholesterolemic rabbits. Evidence-Based Complementary and Alternative Medicine, 2011, 1-8. https://doi:10.1093/ecam/neq003

Shafiee-Nick, R., Afshari, A., Mousavi, S., Rafighdoust, A., Mollazadeh, H., Fanoudi, S., ... Vahedi, M. (2017). A comprehensive review of the potential therapeutic benefits of phosphodiesterase inhibitors on cardiovascular diseases. Biomedicine and Pharmacotherapy, 94, 541-556. https://doi.org/10.1016/j.biopha.2017.07.084

Singleton, V., \& Rossi, J. (1965). Colorimetry of total phenolics with phosphomolybdic phosphotungstic acid reagents. American Journal of Enology and Viticulture, 16, 144-158.

Soutar, A., \& Naoumova, R. (2007). Mechanisms of disease: genetic causes of familial hypercholesterolemia. Nature Clinical Practice Cardiovascular Medicine, 4(4), 214-225. https://doi.org/10.1038/ncpcardio0836

Tong, T., Du-Ok, K., Bo-Sup, K., Kyung-Sik, H., \& Seong-Gook, K. (2015). Beneficial Effect of Seaweed on High-fat Diet-induced Oxidative Stress and Insulin Resistance in Rats. Food Science and Biotechnology, 24(6), 2185-2191. https://doi.org/10.1007/s10068-015-0291-9

Valko, M., Rhodes, C., Moncol, J., Izakovic, M., \& Mazur, M. (2006). Free radicals, metals, and antioxidants in oxidative stress-induced cancer. Chemico-Biological Interactions, 160(1), 1-40. https://doi.org/10.1016/j.cbi.2005.12.009

WHO. (2018). Rapport de l'organisation mondiale de la santé sur la situation mondiale des maladies non trasmissibles. Retrieved from https://www.who.int/fr/news-room/fact-sheets/detail/noncommunicable-diseases

Yamashita, H., Fujisawa, K., Idei, S., Kawaguchi, N., Ito, K. M., Hiemori, M., \& Tsuji, H. (2007). Improvement of obesity and glucose tolerance by acetate in type 2 diabetic Otsuka long-Evans Tokushima fatty (OLETF) rats. Bioscience, Biotechnology Biochemistry, 71, 1236-1243. https://doi.org/10.1271/bbb.60668

You, C., Su, C., \& Zhou, C. (2008). Study on the Effect and mechanisms of Scutellaria baicalensis stem-leaf total flavonoid in regulating lipid metabolism. Journal of Chinese Medicine, 33, 1064-1066.

\section{Copyrights}

Copyright for this article is retained by the author(s), with first publication rights granted to the journal.

This is an open-access article distributed under the terms and conditions of the Creative Commons Attribution license (http://creativecommons.org/licenses/by/4.0/). 